\title{
Pollination and seed dispersal by lizards: a review
}

\author{
Polinización y dispersión de semillas por lagartijas: una revisión
}

\author{
HÉCTOR GODÍNEZ-ÁLVAREZ
}

UBIPRO, FES-Iztacala, UNAM, Avenida de los Barrios 1, Los Reyes Iztacala, Tlalnepantla 54090, Apartado Postal 314, Edo. de México, México; e-mail: chanogod@yahoo.com

\begin{abstract}
This paper reviews the ecological literature published during the last 15 years on pollination and seed dispersal by lizards, in order to determine the possible effects of these animals on plant reproduction. This review is only limited to these years because articles on plant-lizard interactions during this period have used more rigorous experimental approaches than those made previously. All compiled data were analyzed considering the conceptual framework provided by the quantity and quality components of pollination and seed dispersal (i.e., effectiveness), since this information is essential to have an idea of the relative contribution of animals to plant fitness. Results showed that 34 species of lizards feed on nectar and fruits of plants. While lizards consume these plant materials, they could effectively pollinate flowers or disperse seeds to sites away from parent plants. However, more studies on particular aspects of these interactions should be conducted in order to completely understand the ecological and evolutionary effects of lizards on plants.
\end{abstract}

Key words: effectiveness, fruits, mutualism, nectar, pollen.

\section{RESUMEN}

En este artículo se presenta una revisión de la literatura ecológica publicada durante los últimos 15 años sobre la polinización y la dispersión de las semillas por lagartijas, para determinar los posibles efectos de estos animales sobre la reproducción de las plantas. Esta revisión está limitada solamente a estos años debido a que los artículos sobre las interacciones planta-lagartija realizados en este periodo emplearon protocolos experimentales más rigurosos que los trabajos hechos anteriormente. Toda la información obtenida se analizó tomando como base las ideas relacionadas con los componentes de cantidad y calidad de la polinización y la dispersión de las semillas (i.e., efectividad), debido a que estos componentes permiten tener una idea de la contribución relativa de los animales a la adecuación de las plantas. Los resultados mostraron que 34 especies de lagartijas se alimentan del néctar y los frutos de las plantas. Durante el consumo de estos productos, las lagartijas pueden polinizar o dispersar las semillas efectivamente. No obstante lo anterior, es necesario realizar estudios sobre aspectos particulares con el fin de entender completamente los efectos ecológicos y evolutivos de las lagartijas sobre las plantas.

Palabras clave: efectividad, frutos, mutualismo, néctar, polen.

\section{INTRODUCTION}

Pollination and seed dispersal are two important stages in the life cycle of plants that could be directly affected by animals. During these stages, biological interactions between animals and plants may occur in which both groups of organisms benefit. Many animals forage at different species of plants to obtain their food and, from this way, they contribute to transport pollen grains from one flower to another or to disperse seeds to sites away from parent plants with suitable conditions for germination and seedling establishment (Howe \& Westley 1988).
Different groups of animals could participate in these interactions playing an important role in the successful pollination and dispersal of seeds. This phenomenon has been reported in insects, birds, and bats which are among the main pollinators of flowers whereas birds and mammals could disperse the seeds of many species of plants (Abrahamson 1989). However, the role of other groups of vertebrates such as fishes, amphibians, and reptiles in the reproduction of plants has not been deeply understood. Particularly, the role of lizards in pollination and seed dispersal has been considered less important although, since the 
beginning of the 20th century, there is evidence that these organisms consume some reproductive plant parts (Olesen \& Valido 2003). This situation could be due to the idea that most lizards consume animal material and only few species include plant parts in their diets or are strictly herbivorous (Szarski 1962, Pough 1973, Cooper \& Vitt 2002). Additionally, it has been suggested that insular species of lizards are the only ones that consume great quantities of plant material in relation to continental species (van Damme 1999). Despite this fact, studies on the ecology of lizards have indicated that many species have a broad diet which include plant parts such as nectar, flowers, and fruits (Sáez \& Traveset 1995, Corlett 1998). Moreover, some of these studies have suggested that herbivorous lizards could affect the reproduction of several species of plants as well as the vegetation structure of the community (Valido \& Nogales 1994, Pérez-Mellado \& Casas 1997). Lizards also establish tight interactions with some plants, exerting selective forces that affect the evolution of flowers and fruits (van der Pijl 1972, Côrtes et al. 1994, Vasconcellos-Neto et al. 2000, Riera et al. 2002).

All the previous information indicate that lizards play an important role in the reproduction of some plant species. In this regard, it would be interesting to determine whether lizards may contribute to plant fitness. According to studies on pollination and seed dispersal, one way to determine the contribution of a particular animal to plant fitness is through the estimation of two components: quantity and quality (i.e., effectiveness; Herrera 1987, Schupp 1993). In plant-pollinator interactions quantity refers to abundance of pollinator, frequency of pollinator visits, and flower visitation rate whereas quality is related to pollen delivered to stigmas, foraging patterns, and selection of floral sexual stage by the pollinator (Traveset \& Sáez 1997). Similarly, quantity in plantdisperser interactions is a function of the abundance of a disperser, its frequency of visits, and the number of seeds dispersed per visit. Quality refers to percentage and rate of seed germination after passage through the digestive tract as well as to deposition site in which seeds were delivered (Schupp 1993).

This paper reviews the ecological literature published during the last 15 years on mutualistic interactions, in order to determine the possible effects of lizards on plant reproduction. This review is only limited to these years because articles on plant-lizard interactions during this period have used more rigorous experimental approaches than those made previously. Based on the compiled information, the following questions were addressed: (1) What are the lizard species that consume flowers and fruits, including rewards such as nectar or fruit pulp? and (2) Do these lizards could have a potential role in pollination and seed dispersal of plants? In order to answer this last question, the information obtained from the ecological literature was analyzed in the context of quantity and quality components of pollination and seed dispersal. Although there are some articles in the literature that have reviewed mutualistic interactions between lizards and plants (Pérez-Mellado \& Traveset 1999, Olessen \& Valido 2003), to my knowledge, none of these studies have analysed them from the perspective of effectiveness. Therefore, with the information presented in this paper I do not pretend to make an exhaustive revision of the literature, but only to show that, from the perspective of the quantity and quality components, lizards could be an essential factor in the reproduction of certain plant species and, at the same time, what are the topics that deserve more attention to completely understand the role of lizards in these mutualistic interactions.

\section{MATERIALS AND METHODS}

To obtain data used in this review a literature search was made in some journals such as Acta Oecologica, Biological Journal of the Linnean Society, Biological Reviews of the Cambridge Philosophical Society, Biotropica, Copeia, Ecology, Journal of Ecology, Journal of Herpetology, New Zealand Journal of Botany, Oecologia, and Oikos, among others. Additionally, other studies found in these journals and related with diets of lizards were used to complement this literature search. Results from each of the published articles were reviewed to determine whether lizard species consume plant material. If this occurred, then plant parts ingested by lizards were recorded considering only reproductive structures like flowers and fruits and rewards such as nectar and pulp. Additionally, it was recorded the locality in which each study was conducted. Because most of these studies differ in their aims as well as in their results it is impossible to make quantitative comparisons about the relative importance of plants in the diets of lizards. However, these studies were used to have a qualitative idea of the plant species consumed by lizards based only in the presence of plants in 
faeces or stomachs and reports of feeding observations of lizards in the field.

To explore the potential role of lizards in the reproduction of plants, the information obtained from the articles was interpreted using the framework proposed for the quantity and quality components of pollination and seed dispersal (Herrera 1987, Schupp 1993). Thus, in the case of pollination, results related to lizard abundance, frequency of visits per plant or flower, and duration of visits were considered as evidence for the quantity component. In the same manner, the presence of pollen in the body of lizards as well as the fruit set (number of fruits/number of flowers) and the seed set (number of seeds/number of ovules) produced by lizards were considered as estimators of the quality component. For seed dispersal, quantity was determined considering lizard abundance, fruit removal, fruit handling time, and number of seeds per scat whereas quality was estimated with seed germination after gut passage, passage time of seeds through the digestive tract, and habitat use by lizards.

\section{RESULTS}

\section{Nectar and fruit consumption by lizards}

Appendix 1 shows lizard species found in the literature that include plant material in their diets and the reproductive plant parts consumed. In general, the results obtained showed that 34 lizard species of seven different families consume reproductive structures and rewards of plants. These lizard species varied in body size ranging from ca. $45 \mathrm{~mm}$ of snoutvent length (SVL) in Hoplodactylus maculatus to ca. $1500 \mathrm{~mm}$ in Varanus olivaceus. Regarding plants, at least 97 species of 58 different families were consumed by lizards. Of all the plant species recorded, fruits were the most consumed item since it was reported for 30 species of lizards. On the contrary, nectar and flowers were eaten only by 6 lizard species, respectively. With respect to localities, the majority of the studies were conducted in islands $(71 \%)$ compared to those carried out in the mainland $(29 \%)$. In the following paragraphs a general view of each lizard family consuming nectar and/or fruits is given.

\section{Family Cordylidae}

Platysaurus capensis was the only species of this family found in the literature that consumes fruits. This omnivorous lizard feeds on the figs of Ficus cordata only when they are available. However, the quantity of fruit ingested varied according to age and sex since handling behaviour and proportion of a fig eaten differ between males, females, and juveniles (Whiting \& Greeff 1997).

\section{Family Gekkonidae}

Geckos in the genera Hoplodactylus, Naultinus, and Phelsuma consume nectar and fruits of different species of plants. According to results in Appendix 1, this family presents the highest number of species that incorporate nectar in their diets in comparison to the rest of the families. This family also comprehends geckos with diurnal (Naultinus, Phelsuma) and nocturnal (Hoplodactylus) activity (Whitaker 1987, Nyhagen et al. 2001).

\section{Family Iguanidae}

This family includes species with different body sizes that ingest considerable quantities of plant material. Among the main reproductive plant parts consumed by species of this family are flowers and/or fruits, although they may also consume young and mature leaves of different plants. For instance, data on the diet of Iguana iguana indicates that it consumes plant parts from more than 15 species (van Marken 1993). Similarly, the analyses of stomach contents of other lizard species included in this family such as Liolaemus pictus (Willson et al. 1996) and Tropidurus torquatus (Fialho 1990, Côrtes et al. 1994) showed that these species also consume fruits (Appendix 1).

\section{Family Lacertidae}

Information found in the literature regarding lacertids was related only with the genera Gallotia, Lacerta, and Podarcis (Valido \& Nogales 1994, Sáez \& Traveset 1995, Hódar et al. 1996). Species of Gallotia and Podarcis consume mainly flowers and fruits. However, Podarcis lilfordi also consumes the nectar of Crithmum maritimum, Euphorbia dendroides, and Rosmarinus officinalis. Lacerta lepida feeds upon beetles along the year; however, when insect availability decreases, it could also consume fruits of Capparis spinosa and Ephedra dystachia.

\section{Family Teiidae}

Aspidoscelis murinus and Teius teyou were the only species with information on their diet found in this literature search. A. murinus is considered as a generalist feeder that consumes 
a wide variety of flowers, fruits, leaves, and animal material (Dearing \& Schall 1992). Additionally, this species also ingest nectar of Aloe vera. With respect to $T$. teyou, the analysis of its droppings indicates that this species consumes fruits of at least three different species of plants (Varela \& Bucher 2002).

\section{Family Scincidae}

Data related to skinks indicates that species in the genera Cyclodina and Leiolopisma commonly include fleshy fruits in their diets (Appendix 1). However, fruit consumption by these species varies with time of day because there are differences in their activity patterns. Species in the genus Leiolopisma are diurnal whereas those in the genus Cyclodina are nocturnal (Whitaker 1987). In addition to these fruit-eating skinks, Niveoscincus microlepidotus feeds on the nectar and fused petals of Richea scoparia flowers. It has been suggested that consumption of fused petals by this lizard facilitates the seed release from plants (Olsson et al. 2000).

\section{Family Varanidae}

Varanus olivaceus was the lizard with the largest body size (SVL > $1500 \mathrm{~mm}$ ) found in this review that consumes a great quantity of fruits. This varanid may consume fruits of different sizes (1-5 cm diameter), compositions (sugary and lipid-rich fruits), and colors. Apparently, this is the only species in this family that eats fruits in the wild (Corlett 1998).

\section{Pollination and seed dispersal}

Studies found in the literature where lizard effects on pollination and seed dispersal have been evaluated are presented in Tables 1 and 2 . With respect to pollination, data related to the quantity component show that some species of lizards that ingest nectar could be very abundant at flowering plants. Geckos (Hoplodactylus duvauceli, H. maculatus) may attain densities up to 7-8 individuals $\mathrm{m}^{-2}$ of flower cover whereas an average of 2.4 Podarcis lilfordi individuals $\mathrm{m}^{-2}$ of plant cover could feed on a single plant (Whitaker 1987, Sáez \& Traveset 1995). Moreover, lizards differ in the time spent on a plant and in the frequency of visits to the open flowers. Traveset \& Sáez (1997) reported that $P$. lilfordi could remain in a shrub of Euphorbia dendroides from 1 to $5 \mathrm{~min}$. During all this time, the number of flowers visited per minute by this lizard was $0.99 \pm 0.18$ (mean \pm standard error). On the other hand, the foraging bout of Phelsuma ornata lasted ca. 4 min and the mean number of Lomatophyllum tormentorii flowers visited per minute was 0.5 (Nyhagen et al. 2001). Regarding quality component, all reviewed studies reported that pollen adheres to

TABLE 1

Quantity and quality components of pollination by lizards. Quantity: (1) lizard abundance, (2) frequency of visits per plant or flower and/or duration of visits, (-) not evaluated. Quality: (1) presence of pollen, (2) fruit set and/or seed set, (-) not evaluated

Componentes de cantidad y calidad relacionados con la polinización por lagartijas. Cantidad: (1) abundancia de la lagartija,

(2) frecuencia de visita a la planta o flor y/o duración de la visita, (-) no evaluado. Calidad: (1) presencia de polen, (2) producción de frutos y/o semillas, (-) no evaluado

\begin{tabular}{|c|c|c|c|c|}
\hline Lizard species & Plant species & Quantity & Quality & Reference \\
\hline Hoplodactylus duvaceli & Metrosideros excelsa & 2 & 1 & $\begin{array}{l}\text { Eifler (1995), } \\
\text { Whitaker (1987) }\end{array}$ \\
\hline Hoplodactylus maculatus & $\begin{array}{l}\text { Metrosideros excelsa } \\
\text { Phormium tenax } \\
\text { Rhopalostylis sapida }\end{array}$ & 2 & 1 & $\begin{array}{l}\text { Eifler (1995) } \\
\text { Whitaker (1987) }\end{array}$ \\
\hline Hoplodactylus pacificus & Metrosideros excelsa & - & 1 & Whitaker (1987) \\
\hline Phesluma ornata ornata & $\begin{array}{l}\text { Gastonia mauritiana } \\
\text { Lomatophyllum tormentorii }\end{array}$ & 2 & 1 & Nyhagen et al. (2001) \\
\hline Podarcis lilfordi & $\begin{array}{l}\text { Crithmum maritimum } \\
\text { Euphorbia dendroides }\end{array}$ & $\begin{array}{l}1,2 \\
1,2\end{array}$ & $\begin{array}{l}1,2 \\
1,2\end{array}$ & $\begin{array}{l}\text { Pérez-Mellado \& Casas (1997) } \\
\text { Traveset \& Sáez (1997) }\end{array}$ \\
\hline
\end{tabular}




\section{TABLE 2}

Quantity and quality components of seed dispersal by lizards. Quantity: (1) lizard abundance, (2) fruit removal and/or handling time, (3) number of seeds per scat, (-) not evaluated. Quality: (1) seed germination after gut passage and/or passage time through the digestive tract, (2) habitat use by lizards, (-) not evaluated

Componentes de cantidad y calidad relacionados con la dispersión de semillas por lagartijas. Cantidad: (1) abundancia de la lagartija, (2) remoción de frutos y/o tiempo de manejo, (3) número de semillas por excreta, (-) no evaluado. Calidad: (1) germinación después de pasar por el tracto digestivo y/o tiempo de paso por el tracto digestivo, (2) hábitat usado por la lagartija, (-) no evaluado

\begin{tabular}{|c|c|c|c|c|}
\hline Lizard species & Plant species & Quantity & Quality & Reference \\
\hline Ctenosaura pectinata & Spondias purpurea & 3 & 1,2 & Mandujano et al. (1994) \\
\hline Ctenosaura similis & Acacia farnesiana & 3 & 1 & Traveset (1990) \\
\hline Cyclura carinata & $\begin{array}{l}\text { Casasia clusiaefolia } \\
\text { Coccoloba uvifera } \\
\text { Eugenia foetida }\end{array}$ & - & 1 & Iverson (1985) \\
\hline Cyclura rileyi & $\begin{array}{l}\text { Casasia clusiaefolia } \\
\text { Coccoloba uvifera } \\
\text { Eugenia foetida }\end{array}$ & - & 1 & Iverson (1985) \\
\hline Gallotia atlantica & Lycium intrincatum & 3 & 1 & Nogales et al. (1998) \\
\hline Gallotia galloti & $\begin{array}{l}\text { Lycium intrincatum } \\
\text { Neochamaelea pulverulenta } \\
\text { Opuntia dillenii } \\
\text { Rubia fruticosa } \\
\text { Whitania aristata }\end{array}$ & 3 & 1,2 & Valido \& Nogales (1994) \\
\hline Liolaemus pictus & $\begin{array}{l}\text { Nertera granadensis } \\
\text { Relbunium hypocarpium }\end{array}$ & - & 1 & Willson et al. (1996) \\
\hline Platysaurus capensis & Ficus cordata & 2 & - & Whiting \& Greeff (1997) \\
\hline Podarcis lilfordi & $\begin{array}{l}\text { Cneorum tricoccon } \\
\text { Whitania frutescens }\end{array}$ & 2,3 & 1 & $\begin{array}{l}\text { Traveset }(1995) \\
\text { Castilla }(1999,2000)\end{array}$ \\
\hline Teius teyou & Ziziphus mistol & - & 1,2 & Varela \& Bucher (2002) \\
\hline Tropidurus torquatus & $\begin{array}{l}\text { Erythroxylum ovalifolium } \\
\text { Melocactus violaceus }\end{array}$ & 2,3 & 1,2 & $\begin{array}{l}\text { Fialho (1990) } \\
\text { Côrtes et al. (1994) }\end{array}$ \\
\hline
\end{tabular}

lizard bodies while they forage for nectar in flowers. Geckos (Hoplodactylus duvauceli, H. maculatus, $P$. ornata) usually had pollen grains only in their throats whereas lacertids ( $P$. lilfordi) present pollen in the ventral part of their bodies as well as in the snout and throat. Additionally, pollen grains in $P$. lilfordi are more abundant in the ventral than in the dorsal part of the snout. The previous results suggest that lizards, at least geckos and lacertids, may potentially act as pollen vectors favoring pollination among flowers in the same plant or between flowers in different plants. However, only two studies were found in this review in which pollination by lizards was analyzed in detail. The lacertid $P$. lilfordi is the main pollinator of the plants Crithmum maritimum and Euphorbia dendroides in the Balearic Islands of Spain. In both species of plants, $P$. lilfordi enhances plant fitness through an increase in the number of viable embryos $(C$. maritimum; Pérez-Mellado \& Casas 1997) or in the fruit and seed set (E. dendroides; Traveset \& Sáez 1997).

Information about quantity and quality components of seed dispersal indicates that lizards consume fruits of different species of plants and also they affect seed germination. In relation to quantity component, data on fruit removal indicate that $P$. lilfordi remove $92-99 \%$ of the fruit crop produced by the shrub Cneorum tricoccon in the Balearic Islands (Traveset 1995). Similarly, Côrtes et al. (1994) reported that rate of fruit removal by Tropidurus torquatus is 
directly correlated with rate of fruit emergence in the cactus Melocactus violaceus. The previous results on fruit removal by lizards are well complemented with data on the number of seeds found in scats. In this regard, iguanids such as Ctenosaura pectinata and C. similis present 1-6 and 30-50 seeds per scat, respectively. Likewise, $T$. torquatus has a variable number of seeds of $M$. violaceus in its faeces ranging from two to 21 (Traveset 1990, Côrtes et al. 1994, Mandujano et al. 1994). For Liolaemus pictus and P. lilfordi, the number of seeds found in their scats depends on the species of plant ingested. Liolaemus pictus faeces could have 1-8 seeds of Nertera granadensis or 1-14 seeds of Relbunium hypocarpium (Willson et al. 1996). Similarly, when $P$. lilfordi feeds on fruits of Whitania frutescens, their scats have 1-5 seeds whereas if it consumes the fruits of $C$. tricoccon, their faeces present 2-3 seeds only (Traveset 1995, Castilla $1999,2000)$. With respect to the quality component, lizards could have a positive or negative effect on seed germination. Seeds ingested by Gallotia galloti, L. pictus, P. lilfordi, and $T$. torquatus have a higher germination percentage than seeds directly obtained from fruits (Côrtes et al. 1994, Valido \& Nogales 1994, Willson et al. 1996, Castilla 1999, 2000). In contrast, the lizards Ctenosaura pectinata, Cyclura carinata, and $C$. riley decrease the number of germinated seeds in the plants Rubia fruticosa, Lycium intrincatum, and Spondias purpurea, among others (Iverson 1985, Mandujano et al. 1994, Valido \& Nogales 1994). Essays conducted under controlled conditions suggest that seeds could remain in the digestive tract of lizards between one and six days (van Marken 1993, Mandujano et al. 1994, Castilla 2000). This period increases the probability that seeds could be dispersed to sites away from parent plants. However, at present few studies have determined the sites in which seeds are deposited. Mandujano et al. (1994) mentioned that $C$. pectinata frequently defecates seeds of $S$. purpurea in the vicinity of these trees and around the base of hollow trunks of Caesalpinia eriostachys. In a similar way, $C$. similis defecates most of its scats below the crowns of Hippomane mancinella (Traveset 1990). This information supports the idea that lizards are capable to disperse seeds in viable conditions to sites away from parent plants; however, in order to completely understand their effects on plant reproduction it is necessary to evaluate seedling establishment in these sites. Fialho (1990) placed seeds of Erythroxylum ovalifolium on the soil surface at the edges of shrubs simulating seed dispersal by T. torquatus. Of all the seeds placed on the soil surface (194) none germinated after five days. In another study, Valido \& Nogales (1994) analyzing the habitat use by the lacertid $G$. galloti showed that it tended to prefer rocky places. At the same time, these authors also found that three species of plants consumed by this lizard were more frequent on rocky places than on bare ground. Based in these results, they suggest that G. galloti could disperse the seeds of these plants to sites with suitable conditions for germination and establishment to occur.

\section{CONCLUSIONS AND PERSPECTIVES}

The review presented in this paper indicates that several species of lizards feed on nectar and fruits of plants. At the same time, it suggests that while consuming these plant materials, lizards could effectively pollinate flowers or disperse seeds to sites away from parent plants. Although this information is valuable to determine the role of lizards in plant reproduction, more studies should be done in order to completely understand the ecological and evolutionary consequences of these interactions. Diet analysis is the subject that has received more attention; however, further research is needed to determine whether lizards are selective feeders that consume plant items in a different proportion to their availability in the environment (Dearing \& Schall 1992, van Marken 1993). These studies will permit to address questions related to digestion, energy, and nutrients provided by nectar and fruits in comparison to vegetative structures. Pough et al. (1998) indicate that fruits and flowers have large, energy-rich cells that are easily ruptured and their energy and nutrients are readily accessible to lizards in comparison to leaves. Additionally, information on the selectivity of diet is basic to understand pollination and seed dispersal by lizards because preference for a particular set of plants increases the probability to establish tight interactions. Moreover, biotic interactions between lizards and plants could vary along the distributional ranges of both interactants. Results obtained in this review show that insular species of lizards interact with more plant species than those inhabiting mainland. In fact, Olesen \& Valido (2003) have indicated that pollination and seed dispersal by lizards is most common on islands than on mainland. According to these authors, island lizards reach very high densities and experience lower predation risk, expanding their diets to include nectar and fruits. However, more field studies on the diet of continental lizards are necessary to determine whether these differences 
really exist or they are only the reflection of insufficient information.

From a plant's perspective, an effective pollinator must be an abundant and frequent visitor that transports pollen from one flower to another located in the same or different individual. Although the information found on this subject is scarce because only few lizard species have been analyzed with this approach, it suggests that lizards could be considered as effective pollinators of plants. Traveset \& Sáez (1997) analyzing the pollination of Euphorbia dendroides (Euphorbiaceae) found that the lacertid Podarcis lilfordi is the true pollinator of this plant because it increases fruit and seed set in comparison to insects. Other species of lizards mainly in the family Gekkonidae could also potentially act as the main pollen vectors of different species of plants. In this regard, Nyhagen et al. (2001) reported that Phelsuma ornata could carry the pollen of up to $80 \%$ of all plant species in Ile aux Aigrettes, Mauritius. Similarly, data on the activity patterns of geckos in the genus Haplodactylus indicate that their distribution is influenced by the pattern of nectar availability (Eifler 1995). However, more experimental studies related with the analysis of quantity and quality components of pollination are needed, in order to determine whether geckos are effective pollinators. With this information, it will be possible to test an idea proposed by Whitaker (1987) which states that geckos could act as 'nectar robbers' in different species of plants from New Zealand.

Contrary to the information found on pollination, results about seed dispersal indicate that many lizards include a wide variety of fruits in their diets. Thus, species in the families Iguanidae, Lacertidae, Teiidae, Scincidae, and Varanidae could potentially disperse the seeds of different species of plants (van Marken 1993, Mandujano et al. 1994, Willson et al. 1996, Castilla 2000). Seed dispersal is a diffuse coevolutionary process in which a particular animal species interacts with different species of plants. For this reason, it has been suggested that seed dispersers vary in the 'services' provided to plants in terms of the number of seeds deposited in suitable sites and the treatment given to seeds in the gut (Wheelwright \& Orians 1982, Schupp 1993). At present, the information related with the effects of lizards on seed germination and seedling establishment is uncertain since studies found in the literature are contradictory (Iverson 1985, Fialho 1990, Côrtes et al. 1994, Mandujano et al. 1994, Valido \& Nogales 1994, Willson et al. 1996, Castilla 1999, 2000, Varela \& Bucher 2002). Therefore, it is necessary to increase the number of studies on the quality component of seed dispersal (i.e., percentage and rate of seed germination after passage through the digestive tract and deposition site in which seeds were delivered) to properly determine the role of lizards in this mutualistic interaction. Despite this lack of information, some studies have analyzed in a detailed manner the interactions between lizards and plants. Thus, Côrtes et al. (1994) and Vasconcellos-Neto et al. (2000), studying the interaction between the lizard Tropidurus torquatus and the cactus Melocactus violaceus in Brazil, found that the cactus and fruit morphology, the pattern of fruit release, and the germination of seeds may represent a suite of adaptations for dispersal by $T$. torquatus. Based on these results, it is possible to argue that under some special circumstances lizards could exert selective forces on plants. Field studies with other species of lizards and plants in different habitats may provide evidence about these interactions and their possible evolutionary consequences.

Finally, the information presented in this review suggests that analysis of the mutualistic interactions between lizards and plants is a subject that deserves more attention, in order to completely understand the possible ecological and evolutionary effects of lizards on plant reproduction.

\section{ACKNOWLEDGEMENTS}

Leticia Ríos, Julio Lemos, Aurelio Ramírez, Iván Rubio, and two anonymous reviewers kindly provided helpful comments to improve the manuscript. J. Lemos, A. Ramírez, and I. Rubio also provided some of the articles used in this review.

\section{LITERATURE CITED}

ABRAHAMSON WG (1989) Plant-animal interactions. McGraw-Hill, New York, New York, USA. xv+480 pp.

CASTILLA AM \& D BAUWENS (1991) Observations on the natural history, present status, and conservation of the insular lizard Podarcis hispanica atrata on the Columbretes Archipelago, Spain. Biological Conservation 58: 69-84.

CASTILLA AM (1999) Podarcis lilfordi from the Balearic islands as a potential disperser of the rare Mediterranean plant Withania frutescens. Acta Oecologica 20: 103-107.

CASTILLA AM (2000) Does passage time through the lizard Podarcis lilfordi's gut affect germination performance in the plant Withania frutescens? Acta Oecologica 21: 119-124.

COOPER WE \& LJ VITT (2002) Distribution, extent, and evolution of plant consumption by lizards. Journal of Zoology 257: 487-517. 
CORLETT RT (1998) Frugivory and seed dispersal by vertebrates in the Oriental (Indomalayan) region. Biological Reviews of the Cambridge Philosophical Society 73: 413-448.

CÔRTES FJE, J VASCONCELLOS-NETO, MA GARCIA, \& AL TEIXEIRA DE SOUZA (1994) Saurocory in Melocactus violaceus (Cactaceae). Biotropica 26: 295-301.

DEARING DM \& JJ SCHALL (1992) Testing models of optimal diet assembly by the generalist herbivorous lizard Cnemidophorus murinus. Ecology 73: 845858.

EIFLER DA (1995) Patterns of plant visitation by nectarfeeding lizards. Oecologia 101: 228-233.

FIALHO RF (1990) Seed dispersal by a lizard and a treefrog - Effect of dispersal site on seed survivorship. Biotropica 22: 423-424.

HERRERA CM (1987) Components of pollinator "quality": comparative analysis of a diverse insect assemblage. Oikos 50: 79-90.

HÓDAR JA, F CAMPOS \& BA ROSALES (1996) Trophic ecology of the Ocellated lizard Lacerta lepida in an arid zone of southern Spain: relationships with availability and daily activity of prey. Journal of Arid Environments 33: 95-107.

HOWE HF \& LC WESTLEY (1988) Ecological relationships of plants and animals. Oxford University Press, New York, New York, USA. xiii+273 pp.

IVERSON JB (1985) Lizards as seed dispersers? Journal of Herpetology 19: 292-293.

MANDUJANO S, S GALLINA \& SH BULLOCK (1994) Frugivory and dispersal of Spondias purpurea (Anacardiaceae) in a tropical deciduous forest in Mexico. Revista de Biología Tropical 42: 107-114.

NOGALES M, JD DELGADO \& FM MEDINA (1998) Shrikes, lizards and Lycium intricatum (Solanaceae) fruits: a case of indirect seed dispersal on an oceanic island (Alegranza, Canary Islands). Journal of Ecology 86: 866-871.

NYHAGEN DF, C KRAGELUND, JM OLESEN \& CG JONES (2001) Insular interactions between lizards and flowers: flower visitation by an endemic Mauritian gecko. Journal of Tropical Ecology 17: 755-761.

OLESEN, JM \& A VALIDO (2003) Lizards as pollinators and seed dispersers: an island phenomenon. Trends in Ecology and Evolution 18: 177-181.

OLSSON M, R SHINE \& E BA'K-OLSSON (2000) Lizards as a plant's 'hired help': letting pollinators in and seeds out. Biological Journal of the Linnean Society 71: 191-202.

PÉREZ-MELLADO V \& JL CASAS (1997) Pollination by a lizard on a Mediterranean island. Copeia 1997: 593-595.

PÉREZ-MELLADO V \& A TRAVESET (1999) Relationships between plants and Mediterranean lizards. Natura Croatica 8: 275-285.

POUGH FH (1973) Lizard energetics and diet. Ecology 54: 837-844.

POUGH FH, RM ANDREWS, JE CADLE, ML CRUMP, AH SAVITZKY \& KD WELLS (1998) Herpetology. Prentice Hall, New Jersey, USA. $\mathrm{xi}+577 \mathrm{pp}$.
RIERA N, A TRAVESET \& O GARCÍA (2002) Breakage of mutualisms by exotic species: the case of Cneorum tricoccon L. in the Balearic Islands (Western Mediterranean Sea). Journal of Biogeography 29: 713-719.

SÁEZ E \& A TRAVESET (1995) Fruit and nectar feeding by Podarcis lilfordi (Lacertidae) on Cabrera Archipielago (Balearic Islands). Herpetological Review 26: 121-123.

SCHUPP EW (1993) Quantity, quality and the effectiveness of seed dispersal by animals. Vegetatio 107/108: 15-29.

SZARSKI H (1962) Some remarks on herbivorous lizards. Evolution 16: 529.

TRAVESET A (1990) Ctenosaura similis Gray (Iguanidae) as a seed disperser in a central american deciduous forest. American Midland Naturalist 123: 402-404.

TRAVESET A (1995) Seed dispersal of Cneorum tricoccon $\mathrm{L}$. (Cneoraceae) by lizards and mammals in the Balearic islands. Acta Oecologica 16: 171178.

TRAVESET A \& E SÁEZ (1997) Pollination of Euphorbia dendroides by lizards and insects: spatio-temporal variation in patterns of flower visitation. Oecologia 111: 241-248

VALIDO A \& M NOGALES (1994) Frugivory and seed dispersal by the lizard Gallotia galloti (Lacertidae) in a xeric habitat of the Canary Islands. Oikos 70: 403-411.

VAN DAMME R (1999) Evolution of herbivory in lacertid lizards: effects of insularity and body size. Journal of Herpetology 33: 663-674.

VAN DER PIJL L (1972) Principles of dispersal in higher plants. Second edition. Springer-Verlag, New York, New York, USA. xi+161 pp.

VAN MARKEN LWD (1993) Optimal foraging of an herbivorous lizard, the green iguana in a seasonal environment. Oecologia 95: 246-256.

VARELA OR \& EH BUCHER (2002) The lizard Teius teyou (Squamata: Teiidae) as a legitimate seed disperser in the dry Chaco Forest of Argentina. Studies on Neotropical Fauna and Environment 37: 115-117.

VASCONCELLOS-NETO J, ALT DE SOUZA, MM GUIMARÁES \& DM DE FARIA (2000) Effects of color, shape and location on detection of cactus fruits by a lizard. Journal of Herpetology 34: 306309.

WHEELWRIGHT NT \& GH ORIANS (1982) Seed dispersal by animals: contrasts with pollen dispersal, problems of terminology, and constraints on coevolution. American Naturalist 119: 402-413.

WHITAKER AH (1987) The roles of lizards in New Zealand plant reproductive strategies. New Zealand Journal of Botany 25: 315-328.

WHITING MJ \& JM GREEFF (1997) Facultative frugivory in the Cape flat lizard, Platysaurus capensis (Sauria: Cordylidae). Copeia 1997: 811818.

WILLSON MF, C SABAG, JA FIGUEROA, JJ ARMESTO \& M CAVIEDES (1996) Seed dispersal by lizards in Chilean rainforest. Revista Chilena de Historia Natural 69: 339-342. 


\section{APPENDIX 1}

Lizard species found in the literature consuming reproductive plant parts. $\mathrm{N}=$ nectar, $\mathrm{Fw}=$ flowers, $\mathrm{Fr}=$ fruits

Especies de lagartijas encontradas en la literatura que consumen estructuras reproductivas de las plantas. N = néctar, FW = flores, $\mathrm{Fr}=$ frutos

\begin{tabular}{lllll}
\hline Lizards & $\mathrm{N}$ & $\mathrm{Fw}$ & $\mathrm{Fr}$ & Reference \\
\hline
\end{tabular}

Family Cordylidae

Whiting \& Greeff (1997)

Platysaurus capensis

Family Gekkonidae

Hoplodactylus duvauceli

Hoplodactylus granulatus

Hoplodactylus maculatus

Hoplodactylus pacificus

Naultinus grayi

Phelsuma ornata ornata

Phelsuma vinsoni

Family Iguanidae

Ctenosaura pectinata

Ctenosaura similis

Cyclura carinata

Cyclura rileyi

Iguana iguana

Liolaemus pictus

Tropidurus torquatus

Family Lacertidae

Gallotia atlantica

Gallotia galloti

Lacerta lepida

Podarcis lilfordi

Podarcis pituyensis

Family Scincidae

Cyclodina alani

Cyclodina oliveri

Cyclodina whitakeri

Leiolopisma fallai

Leiolopisma grande

Leiolopisma nigriplantare

Leiolopisma otagense f. otagense

Leiolopisma otagense $f$. waimatense

Leiolopisma smithi

Niveoscincus microlepidotus

Family Teiidae

Aspidoscelis murinus

Teius teyou

$\begin{array}{ll}X & X \\ & X\end{array}$

$\mathrm{X}$

$x$

X

$\mathrm{X}$

$\mathrm{X}$

$\mathrm{X}$

$\mathrm{X}$
Podarcis hispanica atrata

$\begin{array}{ccl} & \text { X } & \text { Mandujano et al. (1994) } \\ & \text { X } & \text { Traveset (1990) } \\ & \text { X } & \text { Iverson (1985) } \\ & \text { X } & \text { Iverson (1985) } \\ \text { X } & \text { X } & \text { van Marken (1993) } \\ & \text { X } & \text { Willson et al. (1996) } \\ & \text { X } & \text { Fialho 1990, Côrtes et al. (1994) }\end{array}$

X Nogales et al. (1998)

X Valido \& Nogales (1994)

X Hódar et al. (1996)

X Castilla \& Bauwens (1991)

$\mathrm{X} \quad \mathrm{X} \quad \mathrm{X}$

Sáez \& Traveset (1995), Pérez-Mellado \& Casas (1997) Traveset (1995)

X Whitaker (1987)

X Whitaker (1987)

X Whitaker (1987)

X Whitaker (1987)

X Whitaker (1987)

X Whitaker (1987)

X Whitaker (1987)

X Whitaker (1987)

X Whitaker (1987)

X X Olsson et al. (2000)

Family Varanidae 